\title{
Monogenetic Trematode Infentations in Indian Cat Fishes of River Gomati at District Sultanpur Uttar Pradesh, India
}

\author{
Mishra Surya Prakash
}

Department of Zoology, Ganpat Sahai PG College, Sultanpur Utter Pradesh , INDIA

To Cite this Article

Mishra Surya Prakash, "Monogenetic Trematode Infentations in Indian Cat Fishes of River Gomati at District Sultanpur Uttar Pradesh, India", International Journal for Modern Trends in Science and Technology, 6(8): 120-124, 2020.

\section{Article Info}

Received on 21-June-2020, Revised on 15-July-2020, Accepted on 29-July-2020, Published on 07-August-2020.

\section{ABSTRACT}

Nutrients deficiency is one of the major challenges facing our country. Fishes are good source of aquatic food that provides nutrients and gives nourishment to the human's body and promotes growth. This study was carried out to determine the prevalence of monogenean ectoparasites on fresh water cat fishes of river Gomti at district Sultanpur (U.P.), in a bid to suggesting ways of curbing them. Total 720 fishes consisting of 180 Magur (Clarias), 180 Singhi (Heteropneustes), 180 Parhin (Wallago), and 180 Tengar (Mystus) were screened using standard parasitological procedures. Higher infestation was recorded in Parhin (Wallago) and lower infestation recorded in Singhi (Heteropneustes). Larger fishes recorded higher infestation than smaller ones. Therefore, routine check of physico-chemical qualities and monitoring of parasitic status of fish in river Gomti would reduce the mortality and loss in fish production.

KEYWORDS: Cat fishes, Ectoparasites, Gomti river, Monogenetic trematodes, Sultanpur

\section{INTRODUCTION}

One of the most challenging problems facing our country today is nutrients deficiency. Fishes acts as an important source of macro as well as micronutrients. Protein deficiency is also one of the major global challenges especially in India. The continuous increase in human population requires more food production to meet the consequent increasing demands. With the increasing demands for animal protein, fishes considered to compensate the continuous lack of such elements due to its comparatively low price. Fishes serves as a good source of animal protein for man and his livestock and accounts for more than $40 \%$ of the protein diet of $2 / 3$ of the global population (Obiekezie, 2007 and FAO, 1999). The increasing fish production necessitates the study of pathogens that may affect fish life and / or productivity. The infestation of monogenean ectoparasites represent serious problems affecting the health and development of fisheries. The fishes live in large aggregations provides an opportunity for the spread of parasitic infection as external parasites. Thus the increasing density of fish increases the transmission and multiplication of ectoparasites. Economically ectoparasites formed a great barrier against the development of fish production (Paperna, 1975).

Monogeneans are small to medium sized trematodes which complete the life cycle on one host. In majority of cases, monogeneans cause dual mode of injury to their hosts. Though their hooks and other organs of attachment, they break the continuity at the site of attachment and results 
in the localized hemorrhages. The chief organ of attachment is the haptor, which is posterior, mostly parasitic on gills, some on the body and fins. Some monogenetic trematodes are serious pests in fish culture on occasion. In hatcheries and culture ponds, some dactylogyrids cause great damage to gill filaments and some caused damage on skin and fins of carps (Hoffman, 1967). They usuallyinfect gills, skin and fins and cause damage of host tissue by their haptor, anchors and hooks during feeding. The Magur (Clarias), Singhi (Heteropneustes), Parhin (Wallago) and Tengar (Mystus) are principle fresh water cat fishes of India particularly in eastern Uttar Pradesh. Mortalities of these fishes accompanied by Dactylogyrus and Gyrodactylus infestations of the gills and skin has caused serious concern among the fishermans now a days. These are cosmopolitan ectoparasites occurring highly in larval and adult stages, produce a wide variety of effects on fishes (Chandra et. al.,1996).

The monogenetic trematode infestation affects the normal physiology of fish and produce a weakening of the immune system of the host. This increases their susceptibility to secondary infections such as viruses, fungi, bacteria, protozoans and crustacians. This results in the nutritive devaluation of fish (Onyedineke, et. al., 2010). Parasites also compete with fish for food, there by depriving them of essential nutrients and inhibiting growth. Monogenetic trematodes usually not causing any problem in nature unless the host continuously being reinfested, so that massive number of worms build upon the fish (Mishra, 2020).

From the above literatures, monogenean ectoparasites represents one of the most hazardous threats to fish health and productivity. Some of these parasites may be highly pathogenic and contribute to high fish mortality and economic loss, while in natural systems they may threaten the abundance and diversity of indigenous fish species (Mashego, 2001).

\section{MATERIAL AND METHODS}

For the investigation of monogenean ectoparasites, three sampling stations ( pre city area Kurwar, city area Golaghat and post city area Tatianagar) were selected in the river Gomti at district Sultanpur (U.P.). To observe the seasonal variation three distinct seasons were used as winter season (October - January), summar season (February - May) and rainy season (June September) in the experimental period. Magur
(Clarias), Singhi (Heteropneustes), Parhin (Wallago) and Tengar (Mystus) were selected as experimental fishes and sampled regularly from all sampling stations. Experimental fishes were collected for a period of 12 months from October 2018 to September 2019. Samples were collected from each sampling station at monthly intervals with the help of fisherman. Per month 05 samples of each fish were collected from each sampling station and were transported to the laboratory of department of Zoology, Ganpat Sahai P.G.College Sultanpur with plastic container and bags.

\subsection{Collection of Parasites:}

The monogeneans were collected especially from gill region by using Mizelle's (1936 and 1938) freezing techniques. The external examination were made by scrapping the skin and examining smear using a magnifying glass or by under microscope. Cut both the opercula of fish and remove gills. The dissected gills were placed in petri dish containing clean water and kept in refrigerator for 8-48 hours. The low temperature not only relaxes the parasites but also help in automatic removal of mucous in which these flukes were entangled. Subsequently, the gills were removed, placed in separate tubes, half filled with water and sake vigorously. This solution now poured in clean petridishes, diluted with water and examined under binocular microscope. The live monogeneans were gently rubbed to dislodge from the gill filaments with the help of a triangular pointed needle and forceps as suggested by Malmberg, (1957). The monogeneans were removed and picked out using a fine pipette with a small drop of water on a clean slide and covered with a cover slip (Das, Majumdar and Chandra, 2016).

\subsection{Fixation of Parasites :}

Monogeneans were fixed with a drop of ammonium picrate or Malmberg fixative introduced beneath the cover slip to fix and clean the parasite. Sometimes monogeneans were immediately fixed in $70 \%$ ethyl alcohol or $10 \%$ neutral formaline for further processing. The fixed monogeneans were studied under microscope and their size, shape and chitinoid structure was noted. Then the slides were marked by a permanent marker pen according to probable monogenetic trematode. The identification of the parasites were done following Yamaguti, (1953) and Chandra, (2008).

\subsection{Quantification of Parasites :}

Prevalence, mean intensity and abundance are suitable descriptors to quantify parasites in a hosts. The prevalence, mean intensity of 
infestation and abundance (relative density of parasites) were used after Margolis, et.al.(1982).

Prevalence is the number of disease cases present in a particular population at a given time, where as incidence is the number of new cases that develop during a specified time period. Prevalence is calculated as-

$$
\text { Prevalence }=\frac{\text { Numberofhostinf ested }}{\text { Numberofhostexamined }} \times 100
$$

Mean intensity is the arithmetic mean of the number of individuals of a particular parasite species per infected host in a sample. It is calculated as-

$$
\text { Meanintensity }=\frac{\text { Numberof parasiteobserved }}{\text { Numberoffishinfested }}
$$

Abundance is the arithmetic mean of the number of individuals of a particular parasite species per host examined. It is calculated as-

$$
\text { Abundance }=\frac{\text { Numberof parasiteobserved }}{\text { Numberofhostexamined }}
$$

These measures have different biological interpretations and need different statistical methods to be compared between samples.

\section{OBSERVATIONS}

\section{Seasonal changes in infestations of} monogenean ectoparasites in different hosts :

The prevalence of monogenean ectoparasites were found fluctuated in irregular pattern over the study period. The highest prevalence $(68.33 \%)$ is found in rainy season in Parhin (Wallago) and the lowest (36.67\%) is found in Singhi (Heteropneustes) in summer season. The highest mean intensity and abundance of monogenean infestation were determined as 8.83 and 6.03 respectively in Parhin (Wallago) in rainy season, but the lowest mean intensity and abundance of monogenean infestation were determined as 6.48 and 2.70 respectively in Singhi (Heteropneustes) in summer season. The prevalence of monogenean infestation differ insignificantly $(P \geq 0.05)$ among different cat fishes in each of the season in river Gomti at district Sultanpur ( Table 1).

\begin{tabular}{|c|c|c|c|c|c|c|c|c|}
\hline \multirow{2}{*}{ Season } & \multirow{2}{*}{$\begin{array}{l}\text { Name } \\
\text { of Fish }\end{array}$} & \multicolumn{2}{|c|}{ No. of Host Fish } & \multirow{2}{*}{$\begin{array}{l}\text { Total } \\
\text { No.of } \\
\text { Para } \\
\text { sites }\end{array}$} & \multirow{2}{*}{$\begin{array}{c}\text { Prevalence } \\
\%\end{array}$} & \multirow{2}{*}{$\begin{array}{l}\mathrm{x} 2 \\
\mathrm{df}=3 \\
(P=7.82 \\
)\end{array}$} & \multirow{2}{*}{$\begin{array}{l}\text { Mean } \\
\text { Intensit } \\
y\end{array}$} & \multirow{2}{*}{$\begin{array}{l}\text { Abundanc } \\
\text { e }\end{array}$} \\
\hline & & $\begin{array}{c}\text { Examin } \\
\text { ed }\end{array}$ & $\begin{array}{c}\text { Infeste } \\
d\end{array}$ & & & & & \\
\hline WINTER & $\begin{array}{l}\text { Magur } \\
\text { Singhi } \\
\text { Parhin } \\
\text { Tengar }\end{array}$ & $\begin{array}{ll}60 & 60 \\
60 & 60\end{array}$ & $\begin{array}{l}29 \\
28 \\
36 \\
28\end{array}$ & $\begin{array}{l}221 \\
190 \\
292 \\
212 \\
\end{array}$ & \begin{tabular}{|l|}
48.33 \\
40.00 \\
60.00 \\
46.67 \\
\end{tabular} & 4.28 & $\begin{array}{l}7.62 \\
6.78 \\
8.11 \\
7.57 \\
\end{array}$ & $\begin{array}{ll}3.68 & \\
3.16 & \\
4.87 & \\
3.53 & \end{array}$ \\
\hline SUMMER & $\begin{array}{l}\text { Magur } \\
\text { Singhi } \\
\text { Parhin } \\
\text { Tengar }\end{array}$ & $\begin{array}{l}60 \\
60 \\
60 \\
60\end{array}$ & $\begin{array}{l}26 \\
25 \\
34 \\
25\end{array}$ & $\begin{array}{l}183 \\
162 \\
260 \\
171\end{array}$ & $\begin{array}{l}43.33 \\
36.67 \\
51.67 \\
41.67\end{array}$ & 2.72 & $\begin{array}{l}7.03 \\
6.48 \\
7.65 \\
6.84\end{array}$ & $\begin{array}{l}3.05 \\
2.70 \\
4.33 \\
2.85\end{array}$ \\
\hline RAINY & $\begin{array}{l}\text { Magur } \\
\text { Singhi } \\
\text { Parhin } \\
\text { Tengar }\end{array}$ & $\begin{array}{l}60 \\
60 \\
60 \\
60 \\
\end{array}$ & $\begin{array}{l}32 \\
31 \\
41 \\
34\end{array}$ & $\begin{array}{l}254 \\
218 \\
362 \\
248\end{array}$ & $\begin{array}{l}61.67 \\
51.67 \\
68.33 \\
56.67 \\
\end{array}$ & 2.62 & $\begin{array}{l}7.94 \\
7.03 \\
8.83 \\
7.29\end{array}$ & $\begin{array}{l}4.23 \\
3.63 \\
6.03 \\
4.13\end{array}$ \\
\hline TOTAL & & 720 & 369 & 2773 & 51.25 & & 7.51 & 3.85 \\
\hline
\end{tabular}

Table 1: Seasonal infestations of monogenetic trematode ectoparasites on different cat fishes of river Gomti at district Sultanpur ( one year data recorded during October 2018 to September

Changes in infestations of monogenean ectoparasites in cat fishes in different sampling stations of river Gomti at district Sultanpur :

Among the different sampling stations the highest prevalence(65.00\%) and abundance (4.85) is found in Golaghat sampling station in rainy season and highest mean intensity (8.20) is found in Kurwar sampling station in rainy season. The lowest prevalence (40.00\%) and abundance (3.01) is found in Kurwar sampling station and lowest mean intensity (6.68) is found in Golaghat sampling station in summer season. The prevalence of monogenean infestation differ insignificantly $(P \geq 0.05)$ in different sampling stations in each of the season in river Gomti at district Sultanpur ( Table 2 ). 
Table 2: Infestations of monogenetic trematode ectoparasites on fresh water cat fishes in different sampling stations of river Gomti at district Sultanpur ( one year data recorded during October 2018 to September 2019 ).

\begin{tabular}{|c|c|c|c|c|c|c|c|c|}
\hline \multirow{2}{*}{$\begin{array}{l}\text { Sampling } \\
\text { Stations }\end{array}$} & \multirow[t]{2}{*}{ Seasons } & \multicolumn{2}{|c|}{ No.of Host Fish } & \multirow{2}{*}{$\begin{array}{l}\text { Total } \\
\text { load of } \\
\text { Parasite } \\
\text { s }\end{array}$} & \multirow{2}{*}{$\begin{array}{c}\text { Prevalenc } \\
\text { e } \%\end{array}$} & \multirow{2}{*}{$\begin{array}{l}x 2 \\
\mathrm{df}=2 \\
P=5.9 \\
9\end{array}$} & \multirow{2}{*}{$\begin{array}{l}\text { Mean } \\
\text { intensit } \\
y\end{array}$} & \multirow{2}{*}{$\begin{array}{l}\text { Abundanc } \\
\text { e }\end{array}$} \\
\hline & & $\begin{array}{l}\text { Examin } \\
\text { d }\end{array}$ & $\begin{array}{l}\text { Infeste } \\
\text { d }\end{array}$ & & & & & \\
\hline Kurwar & $\begin{array}{l}\text { WINTER } \\
\text { SUMME } \\
\text { R RAINY }\end{array}$ & $\begin{array}{ll}80 & 80 \\
80 & \end{array}$ & $\begin{array}{ll}35 & 32 \\
40 & \end{array}$ & $\begin{array}{l}272 \\
241 \\
328\end{array}$ & $\begin{array}{l}43.75 \\
40.00 \\
50.00\end{array}$ & 2.85 & $\begin{array}{l}7.77 \\
7.53 \\
8.20\end{array}$ & $\begin{array}{l}3.40 \\
3.01 \\
4.10\end{array}$ \\
\hline Golaghat & $\begin{array}{l}\text { WINTER } \\
\text { SUMME } \\
\text { R RAINY }\end{array}$ & $\begin{array}{l}80 \\
80\end{array}$ & $\begin{array}{ll}46 & 41 \\
52 & \end{array}$ & $\begin{array}{l}331 \\
274 \\
388\end{array}$ & $\begin{array}{l}57.75 \\
51.25 \\
65.00\end{array}$ & 1.71 & $\begin{array}{l}7.19 \\
6.68 \\
7.46\end{array}$ & $\begin{array}{l}4.13 \\
3.42 \\
4.85\end{array}$ \\
\hline $\begin{array}{l}\text { Tatianaga } \\
\mathbf{r}\end{array}$ & $\begin{array}{l}\text { WINTER } \\
\text { SUMME } \\
\text { R RAINY }\end{array}$ & $\begin{array}{l}80 \\
80\end{array}$ & $\begin{array}{ll}40 & 37 \\
46 & \end{array}$ & $\begin{array}{l}312 \\
261 \\
366\end{array}$ & $\begin{array}{l}50.00 \\
46.25 \\
57.50\end{array}$ & 3.22 & $\begin{array}{l}7.80 \\
7.05 \\
7.96 \\
\end{array}$ & $\begin{array}{l}3.90 \\
3.26 \\
4.56 \\
\end{array}$ \\
\hline & TOTAL & 720 & 369 & 2773 & 51.25 & & 7.51 & 3.85 \\
\hline
\end{tabular}

\section{DISCUSSION}

Monogenetic trematode infestations are very common in fresh water cat fishes of India especially of eastern Uttar Pradesh ( Gussev, 1976 ; Tripathi, 1957). During the investigation prevalence of this fluke in Indian cat fishes was quite high and fishes of larger size groups were more susceptible. However, several authors have noted only the correlation between outbreak of monogenetic trematode infestations and stocking densities (Johnsen and Jensen, 1986). It was also observed in our study that monogenetic trematode infestations were higher in case of fishes collected from city area sampling station (Golaghat) as fishes inhabited with highly polluted water. The pre city area sampling station (Kurwar) is less infected than post city area sampling station (Tatianagar) according to pollution status. Thus the polluted water increases the growth of these ectoparasites.

$$
\text { The prevalence of }
$$
monogenetic trematodes in cat fishes was higher in rainy season than winter and summer season. Parhin (Wallago) was more infected than other three experimental cat fishes Magur (Clarais), Tengar (Mystus), and Singhi (Heteropneustes). The food of monogenetic trematode is host's mucous, epithelium and sometimes blood. It causes motality in all stages of fishes, thus resulting great economic losses (Tripathi, 1957 ). Rainy and winter season were the most susceptible period of the year when fish parasites are abundant. This could be due to stocking density and pollution status of river water. Mohan and Bhatta, (2002) reported that monogenetic trematodes are some of the very important pathogens that have had insignificant impact on the yield in Indian fisheries.

In the present study, the fishes of city area sampling station (Golaghat) were found to be more infested with monogenetic trematode parasites as compared to fishes of pre city area (Kurwar) sampling station and post city area (Tatianagar) sampling stations. During the period of investigation, infestation was changed with seasonal variation. The monogenetic trematode infestation was highest in rainy season and lowest in summer season. This result agrees with (Das, 2003; Banerjee and Bandyopadhyay, 2010). Barai and Chandra (2005) reported that the highest monogenetic trematode infestation in fry and fingerlings of fishes were in August and September ( rainy season) because of the highest stocking density. Hossain et.al. (2007) mentioned that increased occurrence of disease in the rainy season might be due to unfavorable environmental condition.

\section{CONCLUSION}

The present study highlighted the infestation of monogenetic trematodes and disease problems in Indian fresh water cat fishes. Monogenetic trematodes were found mainly on gills but sometimes occur on skin and fins of fishes. Infestation begins at the early stage of fish life and persists up to adult stage. Monogenetic trematode infestation also provides platform for secondary infections of protozoans, bacteria viruses and crustacians. The highest infestation of monogenetic trematode was found in Parhin (Wallago). Monogenetic trematodes was a common problem for fresh water cat fishes of India especially in eastern Uttar Pradesh could be 
increased by controlling the monogenetic trematode infestation and diseases.

\section{REFERENCES}

[1] Banerjee, S. and Bandyopadhyay, P.K. (2010): Observation on prevalence of ectoparasites in carp fingerlings in two district of West Bengal. Journal of Parasitic Diseases, 34: 44-47.

[2] Barai, A.K. and Chandra, K.J. (2005): Studies on Helminth (Trematoda : Monogenea) Parasites of Nursery Juvenile carps fish of Mymensingh, Bangladesh, Sindh University Research Journal (Science Series), 37: 25-36.

[3] Chandra, K.J. and Jannat, M.S. (2002) :Monogenean gill parasites of Indian major carps from different fish farms of Mymensingh, Bangladesh. Bangladesh Journal of Fisheries Research, 6: 43-52.

[4] Chandra, K.J. (2006) : A review of fish parasitological studies in Bangladesh. Journal of Agriculture and Rural Development. 4: 9-18.

[5] Chandra, K.J. (2008) : A practical Text Book of Fish Parasitology and Health Management. The University Grant Commission of Bangladesh,pp. 213.

[6] Das, A.K. (2003) : Investigation in to the parasitic infestations of three exotic fishes of Bangladesh. MS Thesis, Department of Aquaculture, Bangladesh Agricultural University, Mymensingh, Bangladesh. pp. 82.

[7] Das, R.D., Majumdar, S. and Chandra, K.J. (2016) : Monogenetic trematodes infestations in Indian Major carps of Mymensingh region. Res. Agric. Livest. Fish Vol. 3 No. 1 April 2016 : 187-194.

[8] FAO (1999) : World production of fish, crustaceans and mollusks by major fishing areas. Fisheries information Data and statistic unit (FIDI), Fisheries Department, F.A.O. Rome.

[9] Gussev, A.V. (1976) : fresh water Indian Monogenoidea, principles of systematics, analysis of the world faunas and their evaluation. Indian Journal of Helminthology, 25/26 : $1-241$.

[10] Hoffman, G.L. (1967) : Lesions due to internal helminthes of fresh water fishes. In the pathology of fishes (eds. W.E.Rebelin and G. Higaki). The University of Wisconsin Press. Madison. Wisconsin, pp. 151-186.

[11] Hossain, M.A., Banu, A.N.H. and Rahman, M.H. (2007) : Prevalence of ectoparasites in carp nursery of Greater Mymensingh. Progressive Agriculture, 5 : 39-44.

[12] Hossain, M.D., Hossain, M.K. and Rahman, M.H. (2007) : Water quality parameters and incidence of fish diseases in some water bodies in Natore, Bangladesh. Journal of Life Earth Sciences, 2: 27-30.

[13] Johnsen, B.O. and Jensen, A.J. (1986) : Infestations of Atlantic Salmosalar by Gyrodactylussalaris in Norwegian rivers. Journal of Fisheries Biology, 29: 214-233.

[14] Majumdar, S. and Agarwal, S.M. (1988) : Studies on monogenean parasites in fresh water fishes at Raipur II. Indian Journal of Helminthology, 40: 93-108.

[15] Malmberg, G. (1957) : On the Occurrence of Gyrodactylus on Swedish fishes. Skec. Sod. Sevr. Fish for Arsskr. 19-76.

[16] Margolis, L., Esch, G.W., Holmes, J.C., Kuris, A.M. and Schad, G.A. (1982) : The use of ecological terms in Parasitology (report of AN AD Hoc) committee of the American Society of Parasitologgists, Journal of Parasite, $68: 131-133$.

[17] Mashego, S.N. (2001) : Redistribution of Proteocephalus glanduligar. Annals Trans. Museum. 38 : 13-17.
[18] Mishra, S.P. (2020) : Monogenetic Trematode Infestations in Indian major carps of Ayodhya division, Uttar Pradesh, India : JETIR July 2020 Vol.7(issue 7) pp. 1920-1928.

[19] Mizelle, J.D. (1936) :New species of trematodes from gills of illionois fishes Amer. Midl. Nat. 17 : 785-806.

[20] Mizelle, J.D. (1938) : Comparative studies on trematodes (Gyrodactyloidea) from gills of North American fresh water fishes. Illionois iol. Mongr. $17: 1-81$.

[21] Mohan, C.V. and Bhatta, R. (2002) : Social and economic impacts of aquatic animal health problems on aquaculture in India. In : J.R. Arthur, M.J. Phillips, R.P.Subasinghe, M.B. Reantaso and I.H. Mac Rac, (eds). Primary Aquatic Animal Health Care in Rural, Small scale. Aquaculture Development. FAO FISH. TECH. Pap. No. 406, pp. 63-75.

[22] Obiekezie, A.J. and Osuigwe, D.I. (2007) : Assessment of the growth performance and feed utilization of fingerlings Heterobranchus longifilis fed new and boiled jack-bean (Canavalia ensiformis) seed meal as fish meal substitute. Int. J. Fish $2: 37-41$.

[23] Onyedineke, N.K., Obi, U., Ofoegbu, P.U. and Ukogo, I (2008) : Helminth Parasites of some Freshwater Fish from River Niger at Illushi Edostate Nigeria. Nig. J. An. Sci. 6 (3) :16-21.

[24] Paperna, I. (1975) : Parasites and diseases of the grey mullet (Mugilidae) with special reference to the seas of the near East. Aqua. 5 : 65-80.

[25] Tripathi, Y.R. (1955) : Studies on the parasites of Indian fishes. Part IV. Trematoda, Monogenea, Microcotylidae. Rec. Ind. Mus. $52:$ 231-247.

[26] Yamaguti, S. (1953) : Parasitic worms mainly from Celebes. Part 2. Monogenetic trematodes of fishes.

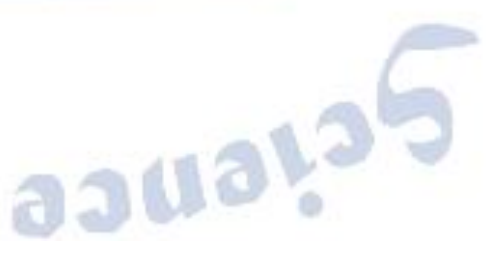

